See discussions, stats, and author profiles for this publication at: https://www.researchgate.net/publication/343330257

\title{
Removal of Copper Ions from Aqueous Solution Using Waste Mill Scales
}

Article in Solid State Phenomena · July 2020

DOI: 10.4028/www.scientific.net/SSP.307.247

CITATIONS

0

9 authors, including:

...

Nur ASYIKIN Nazri

Universiti Teknologi MARA

11 PUBLICATIONS 4 CITATIONS

SEE PROFILE

(8)

Syazana Sulaiman

Universiti Putra Malaysia

11 PUBLICATIONS 6 CITATIONS

SEE PROFILE
READS

65

Raba'ah Syahidah Azis

Universiti Putra Malaysia

156 PUBLICATIONS 536 CITATIONS

SEE PROFILE

Nurul ayuni Mohd Azuan

Universiti Putra Malaysia

3 PUBLICATIONS 0 CITATIONS

SEE PROFILE

Some of the authors of this publication are also working on these related projects:

Magnetic Materials View project

synthesis and characterization of superconductors View project 


\title{
Removal of Copper lons from Aqueous Solution Using Waste Mill Scales
}

\author{
Nur Asyikin A. ${ }^{1,3^{*}}$, Rabaah Syahidah Azis ${ }^{1,2}$, Syazana Sulaiman ${ }^{2}$, \\ Nurul Ayuni Azuan², Abdul Halim Shaari², Hasfalina Che Man ${ }^{4}$, \\ Ismayadi Ismail ${ }^{1}$, Idza Riati Ibrahim ${ }^{1}$, Norlaily Mohd Saiden ${ }^{1,2}$ \\ ${ }^{1}$ Material Synthesis and Characterization Laboratory (MSCL), Institute of Advanced Technology \\ (ITMA), Universiti Putra Malaysia, 43400 Serdang Selangor \\ 2Departments of Physics, Faculty of Science, Universiti Putra Malaysia, 43400 Serdang Selangor. \\ ${ }^{3}$ Center of Foundation Studies, Cawangan Selangor, Universiti Teknologi MARA \\ ${ }^{4}$ Department of Biological and Agricultural Engineering, Faculty of Engineering, \\ Universiti Putra Malaysia, 43400 Serdang, Selangor, Malaysia \\ rabaah@upm.edu.my; asyikin2750@uim.edu.my
}

Keywords: waste mill scales, milling time, iron oxides, Cu ions, removal efficiency (RE).

\begin{abstract}
The optimization of the Copper ions ( $\mathrm{Cu}$ ions) adsorption from aqueous solution for inclusion in prolonged the milling time of the extracted iron oxides from waste mill scales has been investigated. Different milling times were used to reduce the size of the raw mill scale which are 24, 48 and $72 \mathrm{~h}$. The three adsorbents were characterized using XRD, FESEM and VSM. Adsorbents that milled for 72 hours gave pure magnetite from the XRD results. FESEM images revealed that prolonged the milling time might reduced the particle sizes. Magnetic hysteresis revealed that all the samples having ferromagnetic behavior. Batch adsorption experiment had been carried out with the three adsorbents and as the results, adsorbents that milled with 72 hours shown highest removal of $\mathrm{Cu}$ ions with $95 \%$ removal efficiency.
\end{abstract}

\section{Introduction}

Polluted water with heavy metal is dangerous, because metal in water tends to bioaccumulate. It will cause the increase in the concentration of a chemical in a biological organism in water. $\mathrm{Cu}$ ions is among those hazardous metal that are most commonly found in industrial wastewater. Even at a very small amount, $\mathrm{Cu}$ ions can cause severe physiological or neurological damage $[1,2]$. It was previously reported that a permissible level of $\mathrm{Cu}$ in water is $2 \mathrm{mg} / \mathrm{L}$ (milligram/ liter). The potential sources of $\mathrm{Cu}$ ions in industrial effluents include metal cleaning and plating baths, pulp, paper board mills, wood pulp production, the fertilizer industry, etc [3]. Agricultural chemicals by-products are also another source of $\mathrm{Cu}$ waste.

Mill scales predominantly with magnetite $\left(\mathrm{Fe}_{3} \mathrm{O}_{4}\right)$ composed of $93 \%$ iron. Current innovations had successfully change the mill scales waste into a valuable product used in many application such in hydrogen fuel cell, medical imaging and water remediation applications[4].

Therefore, in this work, efforts have been made to produce low-cost adsorbents used to remove $\mathrm{Cu}$ ions from aqueous solution. The exciting properties of iron oxides, coupled to their low toxicity, stability and economic viability, it is ideally used for application in a wide range of emerging fields [5]. In addition, iron oxides have been used as adsorbents for the removal of heavy metal from wastewater, which requires low particle size and homogeneous particle size distribution to achieve enhanced efficiency. Thus, this work is carried out to study the removal of copper metal ions from aqueous solutions using iron oxides as a potential application in waste water treatment. Since $\mathrm{Fe}_{3} \mathrm{O}_{4}$ had higher saturation magnetization, the interest is to produce purified $\mathrm{Fe}_{3} \mathrm{O}_{4}$. Therefore, prolonged the milling time used to get purified $\mathrm{Fe}_{3} \mathrm{O}_{4}$. 


\section{Methodology}

Materials. Waste mill scales were purchased from Perwaja Sdn. Bhd. Terengganu, Malaysia. The waste mill scales has flakes shape structure with diameter $<1 \mathrm{~mm}$. Cu solution was prepared from Copper nitrate $\left(\mathrm{Cu}\left(\mathrm{NO}_{3}\right)_{2}\right)$.

Methods. The waste mill scales were conventionally ball milled using a Pascal Engineering mechanical milling for 24,48 and $72 \mathrm{~h}$. The waste mill scales magnetic separation routes were done similar to previously reported by Azis et. al (2002) and Daud et.al $(2015)[6,7,8,9]$. The magnetite $\left(\mathrm{Fe}_{3} \mathrm{O}_{4}\right)$ yielded from CTST was dried in oven at $120{ }^{\circ} \mathrm{C}$ for $24 \mathrm{~h}$.

The structural and phase composition of samples were analyzed from X-ray diffraction (XRD) pattern, characterized using a Philips Expert PW3040 diffractometer operated at $40 \mathrm{kV}$ and $40 \mathrm{~mA}$ with $\mathrm{CuK} \alpha$ radiation $(\lambda=0.154 \mathrm{~nm})$. The microstructure, particles size and elemental analysis of the samples were observed using a NovaNano 230 field emission scanning electron microscope (FESEM) equipped with Energy-dispersive X-ray spectroscopy (EDX). and magnetic properties were determined using a vibrating sample magnetometer (VSM) (LAKESHORE Model 7404).

$\mathrm{Cu}\left(\mathrm{NO}_{3}\right)_{2}$ salt was used in this experiment to prepare $\mathrm{Cu}$ solution with concentration of $2 \mathrm{mg} / \mathrm{L} .4 \mathrm{mg}$ of $\mathrm{Cu}\left(\mathrm{NO}_{3}\right)_{2}$ salt was stirred with $500 \mathrm{ml}$ deionized water to get $2 \mathrm{mg} / \mathrm{L} \mathrm{Cu}$ (II) concentrations. $100 \mathrm{ml}$ of the solution was mixed with $300 \mathrm{mg}$ of iron oxides. The mixture was stirred for 10 minutes and external magnetic field was applied to separate the magnetic adsorbent and adsorbate from the clean water. The water samples were collected and tested with a DR 4000 $\mathrm{HACH}$ Spectrometer for the concentrations. The removal efficiency (RE) was calculated using Eq. (1):

$$
\frac{E=C_{E}-C_{0} \times 100}{C_{0}}
$$

where $C_{E}$ is the concentration at aequilibrium and $C_{0}$ is initial concentration as prepared.

\section{Results and Discussion}

Fig. 1 shows the XRD spectra of waste mill scales milling at different times. From the XRD analysis there was found that the peaks of the iron oxides were characterized as magnetite $\left(\mathrm{Fe}_{3} \mathrm{O}_{4}\right)$, hematite $\left(\mathrm{Fe}_{2} \mathrm{O}_{3}\right)$ and wustite $(\mathrm{FeO})$. Magnetite peak was observed as the dominant spectra and the diffraction peaks are broadened with increased milling times owing to its small crystallite size. Prolonged the milling time, reduced the crystallite size gives broaden full width of half maximum (FWHM) of XRD spectra.

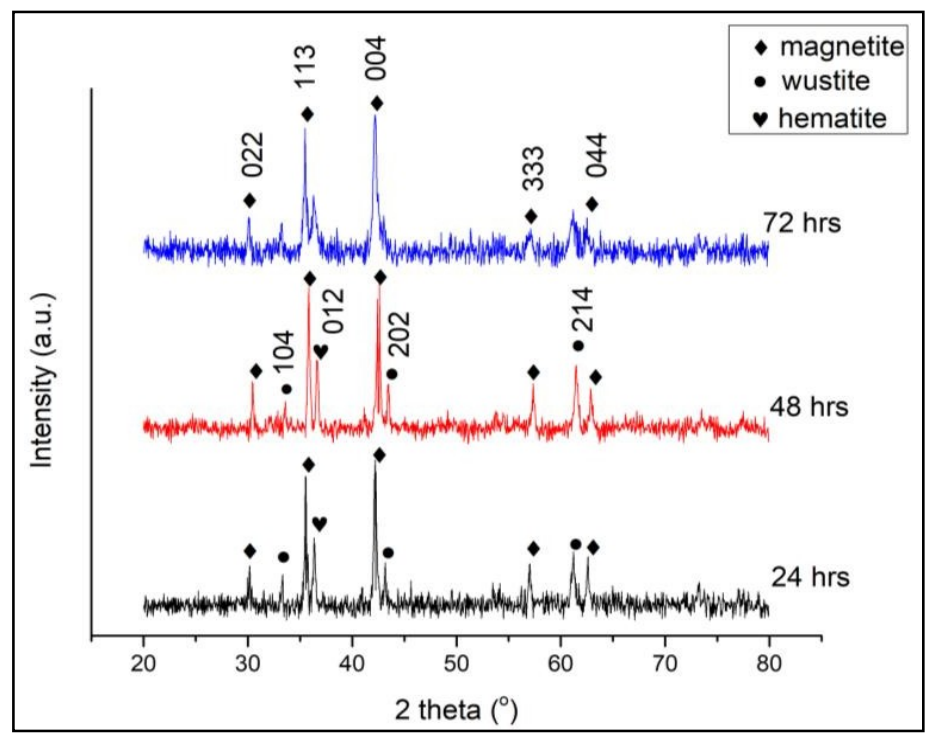

Fig. 1. XRD patterns of 3 samples milled with different time. 
Fig. 2 shows that the morphology and particle size distribution for each samples observed using FESEM. The average particle size was calculated by measuring the size of 200 particles and the histogram of the particle size distribution was plotted. The average particle size for samples milled for 24, 48 and 72 hours are $146 \mu \mathrm{m}, 67 \mu \mathrm{m}$ and $46 \mu \mathrm{m}$, respectively. The magnetic hysteresis loops of samples are shown in Fig. 3, and the magnetic parameters are tabulated in Table 1. The hysteresis loops showed that the iron oxides exhibited a ferromagnetic behavior. Saturation magnetization decreased with smaller particle sizes which having good agreement with previous report by other researcher [4].

Table 1. Magnetic properties of 3 samples.

\begin{tabular}{ll}
\hline Sample & Saturation \\
& Magnetization $(\mathrm{emu} / \mathrm{g})$
\end{tabular}

\begin{tabular}{lll}
\hline $24 \mathrm{hrs}$ & 32.17 & 286.18 \\
$48 \mathrm{hrs}$ & 28.78 & 150.04 \\
$72 \mathrm{hrs}$ & 21.21 & 188.65 \\
\hline
\end{tabular}

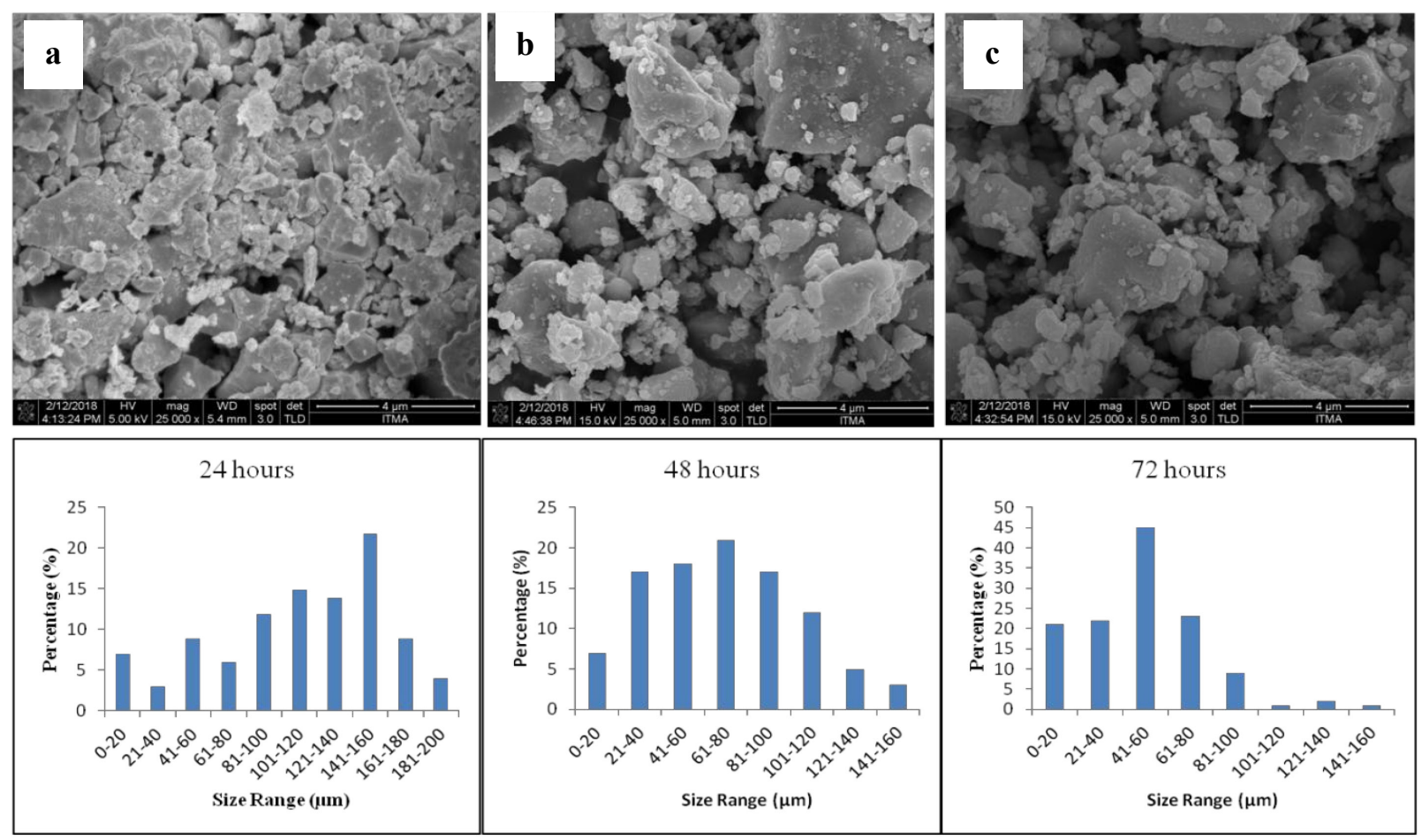

Fig. 2. FESEM images and histogram of particle size distribution for samples milled at a) $24 \mathrm{~h}, \mathrm{~b}$ ) $48 \mathrm{~h}, \mathrm{c}) 72 \mathrm{~h}$.

The removal efficiency (RE) of the $\mathrm{Cu}$ ions by the different particle sizes of iron oxides is shown in Fig. 4. It was observed that by prolonging the milling time, the particle size was decreased. Smaller particle size resulted in increased surface area per unit volume (or mass) of the powder, thus the RE also increased. Therefore, we can observed that the RE is higher at maximum milling hours, $72 \mathrm{~h}$. Fig 5 shows that all the samples equilibrium at 10 minutes adsorption. This shows that the $\mathrm{Cu}$ ions have higher kinetics response to the iron oxides especially for sample milled for 72 hours when it able to remove $95 \%$ of the metal ions within 10 minutes. The ultra fast removal of $\mathrm{Cu}$ ions from the aqueous solution might describe that the physisorptions dominantly occurs. However, $\mathrm{Fe}_{3} \mathrm{O}_{4}$ is an amphoteric solid which can easily protonate and deprotonate. So, there might also chemisorptions occur. The EDX for the elemental analysis before and after adsorption have been presented in Fig. 6 to confirm the presence of copper elements after adsorption. 


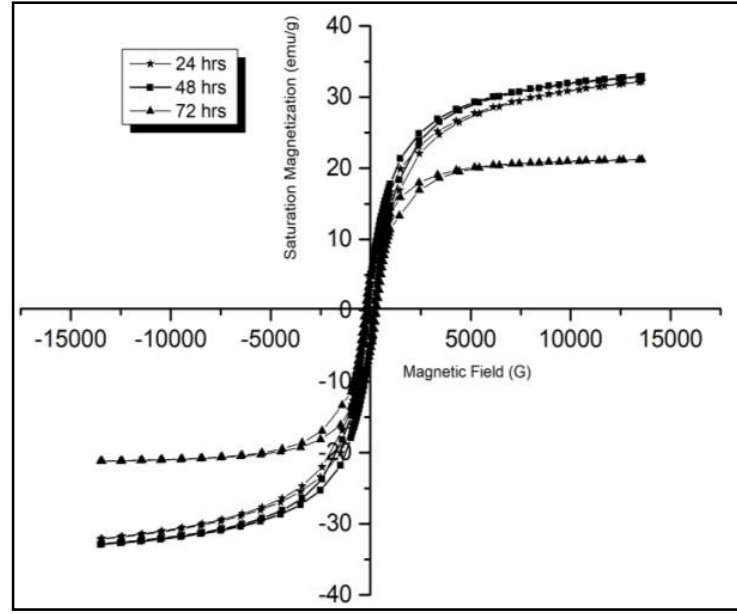

Fig. 3. Hysteresis loop of $24 \mathrm{~h}, 48 \mathrm{~h}$ and $72 \mathrm{~h}$ samples.

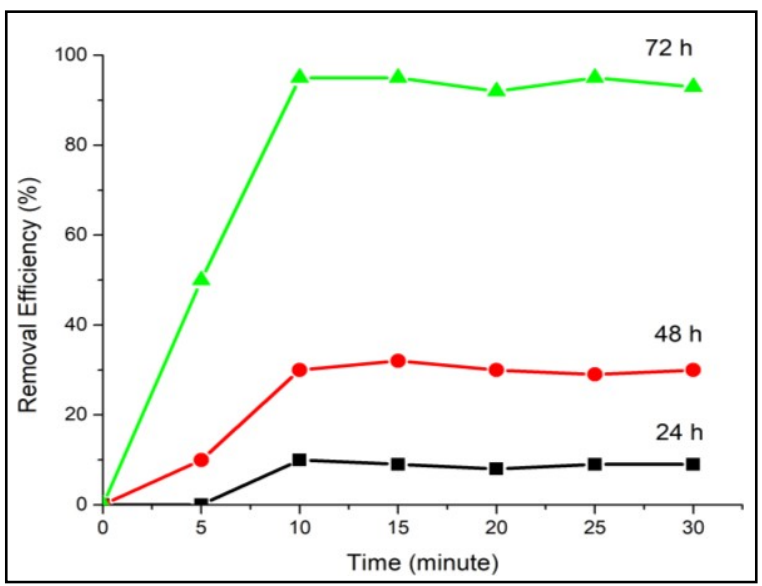

Fig. 5. Graph of removal efficiency against time of adsorption

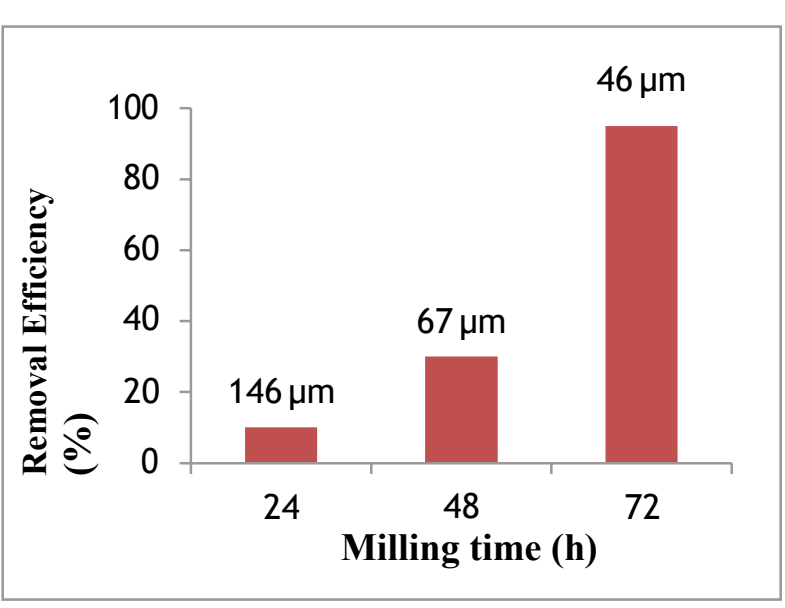

Fig. 4. Graph of removal efficiency against milling time with note the particle size for each samples.

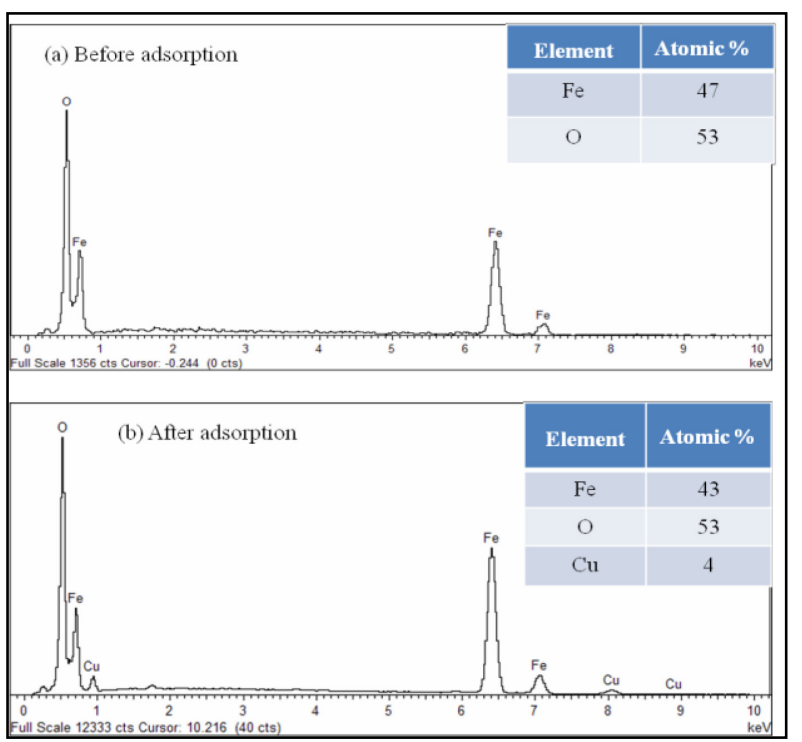

Fig. 6. Percentage of elements from EDX for iron oxides before and after adsorption.

\section{Conclusion}

Through simple separation method, high crystalline iron oxides had successfully extracted and crushed to get micron size with large scale production. With good standing of magnetic properties, the iron oxides give faster $\mathrm{Cu}$ ions removal of $95 \%$ within 10 minutes time. The adsorption was found to be affected by the particle size, magnetic saturation and nature of the magnetite. This finding can be further studies for the application in waste water treatment.

\section{Acknowledgement}

This work was supported by Universiti Putra Malaysia (Research University Grants (9580600)) and the Ministry of Education Malaysia (FRGS). Thanks to the Department of Physics, Faculty of Science and MSCL ITMA, UPM for the measurements facilities. 


\section{References}

[1] Kalpakl, Y., Removal of $\mathrm{Cu}$ (II) from aqueous solutions using magnetite: A kinetic, equilibrium study, Advances in Environmental Research, 4 (2015) 119-133.

[2] Dönmez, G. and Aksu, Z., The effect of copper (II) ions on growth and bioaccumulation properties of some yeasts, Process Biochemistry, 35 (1999) 135-142.

[3] Ho, Y.S., Removal of copper ions from aqueous solution by tree fern, Water Research, 10 (2003) 2323-2330

[4] Azad, A.M., Kesavan, S. and Al-Batty, S., Redemption of microscale mill waste into commercial nanoscale asset. In Key Engineering Materials Trans Tech Publications (2008) $380,229-255$

[5] Parkinson, G. S., Iron oxide surfaces, Surface Science Reports, 111 (2016) 272-365.

[6] Azis, R. S., Hashim, M., Yahya, N., Saiden, N. M., A Study of Sintering Temperatures Variation on Microstructure Developments of Strontium Hexaferrite Millscale-Derived. Journal of Applied Sciences, 2 (2002) 1092-1095.

[7] Azis, R. S., Hashim, M., Yahya, N., Purified Iron Oxide $\alpha-\mathrm{Fe}_{2} \mathrm{O}_{3}$ From Millscale Using Curie Temperature Separation Technique. Journal of Solid State Science and Technology, 9 (2002) 87-90.

[8] Daud, N., Azis, R. S.,Hashim, M., Matori, K. A., Hassan, J., Saiden, N. M., Shahrani, N.M. M., Preparation and Characterization of $\mathrm{Sr}_{1-\mathrm{x}} \mathrm{Nd}_{\mathrm{x}} \mathrm{Fe}_{12} \mathrm{O}_{19}$ Derived From Steel Waste Product via Mechanical Alloying. Materials Science Forum, 846 (2015) 403-409.

[9] Azis, R. S., Syazwan, M. M., Shahrani, N. M. M., Hapishah, A. N., Nazlan, R., Idris, F. M., Ismail, I., Zulkimi, M. M. M., Ibrahim, I. R., Abbas, Z., Saiden, N. M., Influence of sintering temperature on the structural, electrical and microwave properties of yttrium iron garnet (YIG). Journal of Materials Science Materials in Electronics, 29 (2018) 8390-8401.

[10] Suryanarayana, Challapalli. Mechanical alloying and milling, Progress in materials science, 46 (2001) 1-184. 